\title{
Tafsir Alquran Kontemporer: Kajian atas Tafsir Tematik-Kontekstual Ziauddin Sardar
}

\author{
Taufan Anggoro \\ Pascasarjana UIN Sunan Kalijaga Yogyakarta, Indonesia \\ anggoro426@gmail.com
}

DOI: http://dx.doi.org/10.29240/alquds.v3i2.1049

Submitted: 2019-08-28 | Revised: 2019-10-07 | Accepted: 2019-10-31

\begin{abstract}
Ziauddin Sardar is a Muslim thinker who interprets the Koran in a thematiccontextual, with a very critical presentation. Sardar's interpretation is contained in one of his works entitled Reading the Qur'an: The Contemporary Relevance of the Sacred Text of Islam. This article aims to examine the thoughts of Sardar in terms of interpreting the Qur'an. The extent to which the methodology used by Sardar in interpreting the Qur'an. By using descriptive-analytical methods and hermeneutical-analysis techniques, Sardar's interpretation is examined to what extent hermeneutic operational forms appear within them. It also examined how the influences of other figures in 'shaping' Sardar's interpretation. The results of this study show that Sardar's contextual interpretation reveals forms of hermeneutic surgery. Where more 'aiming' aspects of the context and contextualization of the Qur'an. Then methodologically, Sardar's interpretation was influenced by Rahman's double movement theory, and Saeed's legal ethico theory. Then the style of "Hermeneutics of Liberation" Farid Esack was strongly felt in the contextualization of the Koran by Sardar. Sardar's efforts are not limited to explaining the meaning of the Qur'an, but digging into the substance of the text that is manifested in the form of al-Qur'an's social criticism of various religious phenomena today.
\end{abstract}

Keywords: Thematic Interpretation; Contextual; Contemporary; Ziauddin Sardar

Abstrak. Ziauddin Sardar merupakan salah seorang pemikir Muslim yang menafsirkan al-Qur'an secara tematik-kontekstual, dengan pemaparan yang sangat kritis. Penafsiran Sardar tersebut dituangkan dalam salah satu karyanya yang berjudul Reading the Qur'an: The Contemporary Relevance of the Sacred Text of Islam. Artikel ini bertujuan untuk mengkaji pemikiran Sardar dalam hal penafsiran al-Qur'annya. Sejauh mana metodologi yang dipakai Sardar dalam menafsirkan al-Qur'an. Dengan menggunakan metode deskriptifanalisis dan teknik analisis-hermeneutis, penafsiran Sardar dikaji sejauh mana bentukbentuk operasional hermeneutik nampak didalamnya. Selain itu juga dikaji bagaimana keterpengaruhan tokoh-tokoh lain dalam 'membentuk' penafsiran Sardar. Hasil dari kajian ini menunjukkan bahwa penafsiran kontekstual Sardar menampakkan bentukbentuk operasi hermeneutik. Dimana lebih 'membidik' aspek konteks dan 
kontekstualisasi al-Qur'an. Kemudian secara metodologis, penafsiran Ziauddin Sardar mendapat pengaruh dari teori double movement Fazlur Rahman, dan teori ethico legal Abdullah Saeed. Lalu corak "Hermeneutika Pembebasan" Farid Esack sangat terasa dalam kontekstualisasi al-Qur'an yang dilakukan Sardar. Upaya Sardar tersebut tidak hanya sebatas menjelaskan makna al-Qur'an saja (seperti mufassir pada umumnya), tetapi menggali substansi teks yang diwujudkan dalam bentuk kritik sosial al-Qur'an atas berbagai fenomena keberagamaan di masa kini.

Kata Kunci: Tafsir Tematik; Kontekstual; Kontemporer; Ziauddin Sardar

\section{Pendahuluan}

Khazanah penafsiran al-Qur'an terus berkembang seiring berjalannya waktu, dengan secara konsisten memunculkan penafsiran-penafsiran baru dengan berbagai gaya dan model yang dipakai. Baik itu melalui pendekatan tekstualnya, maupun kontekstualnya. Baik itu yang tetap mempertahankan dengan menggunakan metode tahlili ataupun ijmalinya, hingga yang terkini melalui tafsir maudùt nya.

Tafsir maud $\ddot{u}^{\prime} i$ di masa kini memang lebih banyak digunakan oleh para ahli tafsir dalam menafsirkan al-Qur'an. Selain karena dilatarbelakangi keinginan memahami teks al-Qur'an secara utuh, juga di sisi lain berbagai persoalan masa kini yang menuntut para pengkaji tafsir untuk dapat 'menyajikan' tafsir yang secara spesifik relevan dengan isu-isu kekinian. ${ }^{1}$

Pada perkembangan lebih lanjut, lahir beberapa produk tafsir yang menggunakan model tafsir tematik ini. Hal ini tak lepas dari tokoh Abdul Hayy al-Farmawi yang turut meletakkan prinsip-prinsip dasar dalam tafsir mandü $\imath$ (tematik) ini. Menurut al-Farmawi, tafsir tematik ada dua bentuk, yaitu tematik surat dan tematik tema. ${ }^{2}$

Namun, pada masa kini terdapat satu tafsir tematik al-Qur'an yang menggunakan dua model tersebut dalam satu kitabnya. Suatu upaya yang jarang diadopsi oleh tafsir-tafsir tematik masa kini, yang mana lebih dominan menonjolkan aspek isu yang diusung (tema-tema). Karya tafsir tematik yang dimaksud dalam pembahasan ini adalah yang berjudul Reading the Qur'an: The Contemporary Relevance of the Sacred Text of Islam karya Ziauddin Sardar.

Ziauddin Sardar (untuk selanjutnya disebut dengan Sardar) menggunakan dua model tafsir tematik dalam satu karyanya, yaitu tematik surat dan tematik konsep (topik/tema). Dua surat pertama (Surat al-Fätihah dan alBaqarah) ditafsirkan secara tematik surat, lalu penafsirannya dilanjutkan dengan

1 Muhammad Abdul Halim, Menafsirkan al-Qur'an dengan al-Qur'an (Bandung: MARJA, 2012), 9.

2 Abdul Hayy al-Farmawi, Metode Tafsir Maudu'i dan Cara Penerapannya terj. Rosihon Anwar (Bandung: Pustaka Setia, 2002), 42-43. 
metode tematik tema berdasarkan isu-isu kontemporer yang telah ditentukan. ${ }^{3}$ Selain itu, bidang keahlian Sardar sendiri merupakan kajian seputar Sains Islam, bukan pengkaji tafsir. Ini yang kemudian menjadikan penulis tertarik untuk meneliti tafsir tematik Ziauddin Sardar tersebut.

Penelitian-penelitian terdahulu yang mengkaji Ziauddin Sardar sebenarnya telah ada beberapa. Akan tetapi, dari penelitian-penelitian tersebut lebih banyak yang mengkaji sisi pemikiran Ziauddin Sardar tentang Islamisasi Ilmu Pengetabuan. ${ }^{4}$ Adapun yang meneliti secara spesifik penafsiran al-Qur'an Sardar hanya sebatas model penafsiran kontekstualnya, belum secara rinci mengkaji bagaimana metode penafsiran yang ditempuh oleh Sardar.

Oleh karena itu, penelitian ini berupaya mengungkap bagaimana metodologi penafsiran yang dipakai oleh Sardar dalam tafsirnya. Sejauh mana penafsirannya dalam menggali aspek teks, konteks, dan kontekstualisasi alQur'an. Selain itu, juga mengkaji aspek keterpengaruhan tokoh dalam penafsiran Sardar. Hal ini penting karena untuk mengetahui sejauh mana kekhasan penafsiran Sardar dalam karyanya tersebut.

Untuk mengkaji beberapa poin tersebut maka penelitian ini menggunakan metode deskriptif-analisis. Tidak hanya sekedar menggambarkan dan memaparkan, namun juga menganalisis bagaimana eksplorasi yang dilakukan Sardar dalam penafsirannya. Lebih spesifik lagi, agar mendapatkan hasil penelitian yang lebih 'tajam', analisis hermeneutis dipakai dalam penelitian ini. Harapannya tentu agar dapat diketahui seberapa jauh analisis yang dilakukan oleh Sardar dalam menafsirkan al-Qur'an.

Kajian terhadap penafsiran al-Qur'an Sardar disini juga diharapkan mampu membuka lingkup penafsiran menjadi lebih luas lagi. Penafsiran tidak hanya sebatas menjelaskan makna al-Qur'an semata, tapi juga mampu mengungkap kritik sosial al-Qur'an atas fenomena keberagamaan masa kini.

3 Sardar melihat kondisi umat Islam yang masih terkungkung dengan interpretasi-interpretasi masa lalu. Sehingga menjadikan Islam berkarakter kaku, tidak cukup 'berani' untuk melakukan interpretasi-interpretasi baru. Ini menjadikan umat Islam tidak mampu merespon perkembangan zaman. Dalam Masthuriyah Sa'dan, "Islamic Science, Nature, and Human Beings: A Discussion on Ziauddin Sardar's Thoughts", Jurnal Walisongo 23, no. 2 (2015): 236, doi:10.21580/ws.2015.23.2.278.

4 Islamisasi Ilmu Pengetahuan merupakan proses pemurnian atau pengembalian sebuah ilmu pengetahuan kepada suatu prinsip tauhid yakni kesatuan sumber dan makna kebenaran ilmu tersebut. Wacana ini digagas pertama kali oleh Ismail Raji al-faruqi, lalu dilanjutkan oleh Syed Muhammad Naquib Al-Attas. Dalam Kurnia Sari Wiwaha, "Epistemologi Paradigma Islam: Studi Pemikiran Ziauddin Sardar" , Religious: Jurnal Studi Agama-Agama dan Lintas Budaya III, no. 1 (2018): 71, doi: $10.15575 /$ rjsalb.v3i1.3314. 
Sehingga pada sisi inilah makin memperkaya khazanah penafsiran al-Qur'an di era kontemporer seperti saat ini.

\section{Biografi Ziauddin Sardar}

Ziauddin Sardar lahir pada 31 Oktober 1951 di Punjab, Pakistan. Walaupun lahir di Pakistan, Sardar pada tahun 1961 tinggal di Inggris bersama kedua orangtuanya. Pendidikan terakhirnya ditempuh pada jenjang doktor di bidang fisika. Di Inggris, pada tahun 1982 Sardar bekerja sebagai jurnalis dan reporter televisi untuk London Weekend Television. Kemudian pada tahun 2000 Sardar menjadi kolumnis tetap di Majalah New Statesmen selama beberapa tahun, dan pernah pula menjabat sebagai Komisaris untuk Kesetaraan dan Komisi Hak Asasi Manusia (HAM). Selain itu, Sardar juga pernah menjadi anggota interim Forum Keamanan Nasional. ${ }^{5}$

Selama hidup di Inggris, Ziauddin Sardar merasakan kehidupan sebagai seorang muslim yang dipinggirkan. Hal yang sama juga dialami oleh kaum Muslim Inggris secara umum. Ini dikarenakan situasi saat itu, dimana orangorang (pribumi) Inggris khawatir terhadap meningkatnya jumlah kelompok masyarakat Muslim Inggris. Maklum saja, saat itu kesan yang ada di khalayak orang (pribumi) Inggris terhadap keberadaan masyarakat Muslim sangat negatif. ${ }^{6}$ Situasi dan kondisi konflik sosial seperti inilah yang dialami oleh Ziauddin Sardar selama tinggal di Inggris.

Sepanjang hidupnya bahkan hingga kini, Ziauddin Sardar concern pada aktifitas-aktifitas pengintegrasian Islam dan ilmu pengetahuan. Maka tak heran apabila Sardar turut aktif mengkampanyekan tentang Islamisasi ilmu pengetahuan. Fokusnya, pada penciptaan suatu ilmu pengetahuan yang dinamakan sebagai Islam kontemporer, atau yang lebih dikenal dengan epistemologi Islam. Epistemologi Islam disini lebih menekankan pada pengetahuan yang didasarkan dan digali dari nilai-nilai Islam itu sendiri. ${ }^{7}$

Sebagai seorang penulis, Sardar telah menerbitkan lebih dari 45 buku, diantaranya adalah: Mubammad: Aspects of a Biography (1978); The Future of Muslim

${ }_{6}^{5}$ Dalam http: www.ziauddinsardar.com

${ }^{6}$ Contoh kecilnya seperti ketika rencana Muslim Inggris saat itu yang akan mendirikan sekolah Islam. Rencana tersebut dianggap masyarakat Inggris sebagai sebuah ancaman peradaban Barat. Akibatnya, Muslim Inggris saat itu dianggap sebagai rintangan yang harus dihilangkan. Dalam Masthuriyah Sa'dan, "Islamic Science, Nature, and Human Beings", 236.

${ }^{7}$ Sebagai seorang muslim, melihat perkembangan ilmu pengetahuan di negara muslim saat ini yang sangat lamban, tentu saja Sardar khawatir kalau nasib ilmu pengetahuan di negara-negara muslim tidak dikembangkan sesuai dengan perubahan dan tuntutan zaman serta kebutuhan-kebutuhan masyarakat muslim. Dalam Ziauddin Sardar, Merombak Pola Pikir Intelektual Muslim terj. Agung Prihantoro \& Fuad Arif Fudyartanto (Yogyakarta: Pustaka Pelajar, 2000), 11. 
Civilization (1979); Islam: Outline of a Classification Scheme (1979); Islam: Outline of a Classification Scheme (1979); Can Science Come Back to Islam? (1980); Science and Technology in The Middle East: A Guide to Issues, Organisations and Institusions (1982); The Touch of Midas: Science, Value, and Environment in Islam and The West (1984); Arguments for Islamic Science (1984); Futures Islam: The Shape of Ideas to Come (1985); Information and The Muslim World (1988); Postmodern and the Other (1998);8

Kemudian masih ada beberapa karya-karyanya seperti Orientalism (1999); The A to Z of Postmodern Life (2002); Why do People Hate America (2002); Desperately Seeking Paradise: Journeys of a Sceptical Muslim (2004) dan masih banyak lagi karyakarya yang dihasilkan Sardar. ${ }^{9}$ Bahkan beberapa tahun terakhir, Ziauddin Sardar masih saja menampakkan produktifitasnya dalam hal 'melahirkan' karya tulis. Seperti pada tahun 2016 Sardar menulis buku yang berjudul Islam Beyond the Violent Jihadis, lalu pada tahun 2017 Rethinking Reform in Higher Education (bersama Jeremy Henzel-Thomas). Dan pada tahun 2018 terbit bukunya yang berjudul $A$ Person of Pakistani Origins. ${ }^{10}$

Ziauddin Sardar terus melahirkan berbagai karya tulis, tercatat sejak kurun awal tahun 2000 hingga kini (2019). Ini membuktikan bahwa Sardar secara konsisten memperjuangkan ide-ide yang digagasnya dulu hingga kini, dengan terus memberikan respon terhadap permasalahan yang ada pada setiap masanya. Dari pemaparan biografi Ziauddin Sardar memang tidak diketahui secara rinci pendidikan yang ditempuh olehnya.

Riwayat pendidikan Sardar hanya diketahui sedikit saja, seperti yang telah disebutkan pada pemaparan di atas. Namun secara umum, dengan melihat berbagai karya dan pemikirannya, background keilmuan Sardar lebih dominan pada seorang saintis. Berbeda dengan para ahli tafsir mainstream yang mempunyai background keilmuan keislaman dengan berbagai cabang yang ada di dalamnya. Ini tentu akan menjadi bahan analisis pada pembahasan berikutnya, bagaimana keterkaitan background keilmuan seseorang dengan penafsiran yang dihasilkan.

\section{Seputar Buku Reading The Qur'an: The Contemporary Relevance of The Sacred Text of Islam karya Ziauddin Sardar}

Karya tulis Ziauddin Sardar yang berjudul Reading The Qur'an: The Contemporary Relevance of The Sacred Text of Islam ${ }^{11}$ ini merupakan karya tunggalnya

8 Ziauddin Sardar, Islam Tanpa Syariat: Menggali Universalitas Tradisi, ed. Abdul Mu’ti \& Ahmad Najib Burhani (Jakarta: Grafindo Khazanah Ilmu, 2005), 210-223.

${ }^{9}$ Ibid., 227.

${ }^{10}$ Dalam https://ziauddinsardar.com/bibliography yang diakses pada tanggal 7 Juli 2019 Pukul 13.30 WIB.

11 Buku ini diterbitkan oleh Oxford University Press pada tahun 2011, dengan ketebalan buku 393 halaman. Karya Sardar ini kemudian diterjemahkan ke dalam 
dibidang tafsir al-Qur'an. ${ }^{12}$ Karya tafsir al-Qur'annya ini termasuk tafsir maudü’’, karena penafsiran di dalamnya disusun secara tematik, yaitu tematik surat maupun tematik secara topik pembahasan (tema-tema). Sekilas memang cukup unik, karena menggabungkan dua model tafsir tematik yang berbeda dalam satu buku.

Jadi, dalam satu buku tersebut memuat pertama, tafsir surat dan yang kedua, tafsir tematik. Tafsir surat dipakai oleh Ziauddin Sardar untuk menafsirkan dua surat pertama al-Qur'an, yaitu Surat al-Fätihab dan Surat alBaqarah. ${ }^{13}$ Kemudian pada pembahasan berikutnya, Sardar menafsirkan alQur'an dengan didasarkan pada topik-topik kontekstual yang telah ditetapkan sejumlah 22 topik. Suatu langkah yang jarang ditempuh oleh ahli tafsir pada umumnya, yang lebih memilih menggunakan salah satunya.

Ziauddin sardar menyusun karyanya tersebut bukan tanpa alasan. Sardar menulis karyanya tersebut dalam rangka upayanya memahami bagaimana arti alQur'an di abad ke-21 ini. Bagaimana membaca al-Qur'an sesuai kerangka alQur'an itu sendiri, lalu melebur dalam jalinan teksnya tanpa ada tendensi negatif. Menurutnya, itu semua merupakan tantangan bagi seluruh manusia, baik itu muslim maupun non-muslim sekalipun. ${ }^{14} \mathrm{Hal}$ ini terkait dengan pandangan Sardar yang menilai al-Qur'an diturunkan kepada seluruh manusia sebagai petunjuk.

Buku ini terdiri dari 4 bagian (four part) penjelasan, lalu diakhiri dengan penjelasan penutup berupa epilog dari Sardar sendiri seputar penafsiran alQur'an. Pada bab pertama ini memuat pengantar yang berisi penjelasan Sardar tentang metodologi yang dipakai dalam menafsirkan al-Qur'an. ${ }^{15}$ Pengantar dalam suatu karya tafsir merupakan hal yang lumrah dicantumkan oleh penulisnya.

beberapa bahasa. Satu diantaranya diterjemahkan ke dalam Bahasa Indonesia oleh Penerbit SERAMBI dengan judul Ngaji Quran di Zaman Edan: Sebuah Tafsir untuk Menjawab Persoalan Mutakbir pada tahun 2014.

${ }^{12}$ Bukunya ini diambil dari blog "al-Qur'an Project" yang dikelola oleh salah satu majalah harian Inggris, The Guardian. Dengan sedikit penambahan, pengubahan, dan penyelarasan akhirnya diterbitkan menjadi sebuah buku.

13 Sardar mengungkapkan, Surat al-Fätihah dan Surat al-Baqarah ditafsirkan secara tafsir surat karena keduanya merupakan ringkasan pesan Allah kepada manusia. Terlebih al-Baqarah yang menurutnya membahas berbagai topik yang meliputi banyak hal. Dengan menelaah kedua surat tersebut merupakan jalan 'tercepat' untuk menciptakan fondasi bagi pemahaman al-Qur'an secara menyeluruh. Dalam Ziauddin Sardar, Reading The Qur'an: The Contemporary Relevance of The Sacred Text of Islam (New York: Oxford University Press, 2011), 60-61.

${ }^{14}$ Ibid., 15.

${ }^{15}$ Ibid., 21-42. 
Namun, karya Sardar yang sedang dikaji ini mempunyai keunikan, dimana sang penulis turut memaparkan pengalaman hidupnya selama berinteraksi dengan al-Qur'an. ${ }^{16}$ Dari sisi referensi yang digunakan, karya Sardar ini semuanya memakai referensi buku-buku berbahasa Inggris. Kalaupun ada referensi klasik, maka Sardar memakai referensi klasik yang telah diterjemahkan ke dalam Bahasa Inggris.

Referensi yang digunakan lebih banyak karya-karya dari para pemikir progresif, sehingga muatan kritis-argumentatif dalam tafsir tematik Ziauddin Sardar ini sangat terasa. Walaupun referensinya lebih banyak dari sumbersumber non-klasik, karya Sardar tersebut tetap dinyatakan sebagai "Tafsir alQur'an". Sisi kelebihan yang perlu dicatat ialah bahwa karya tafsir Ziauddin Sardar ini menurut penulis sangat mencerminkan sisi inklusifitasnya.

Sisi inklusifitas penafsiran tersebut nampak dalam setiap pemilihan diksi yang lebih mengarah kepada manusia secara umum, sehingga lebih 'terbuka' kepada siapapun, bahkan lintas agama (keyakinan) sekalipun. Kesan yang didapat ialah karya Sardar ini tidak "Muslim sentris". Ini sejalan dengan pendapat Sardar yang memandang al-Qur'an merupakan kumpulan pesan-pesan moral yang ditujukan untuk seluruh umat manusia. ${ }^{17}$ Selain itu, analisis teks di dalamnya sangat sedikit, sehingga semua kalangan dapat membacanya tanpa terkendala adanya penggunaan kosa kata Bahasa Arab, yang seringkali membuat bingung para pembacanya.

\section{Menafsirkan al-Qur'an di Abad 21 menurut Ziauddin Sardar}

\section{Menafsirkan al-Qur'an melalui Tafsir Tematik (Mauḍ ūî)}

Pada bagian ini akan dijelaskan lebih lanjut tentang contoh dan model tafsir tematik yang ditempuh oleh Sardar. Untuk jenis tafsir tematik yang pertama, yaitu tematik surat dapat dijumpai dalam penafsiran Surat al-Fatihah berikut.

Ziauddin Sardar membagi penafsiran Surat al-Fätihah ini menjadi dua bagian, bagian pertama menjelaskan tentang Sifat-sifat Allah, lalu bagian kedua menjelaskan tentang makna Jalan yang Lurus. Semuanya diawali dengan memaparkan terjemah tiap-tiap ayat, lalu menafsirkannya. Berikut penafsiran Surat al-Fatihah bagian pertama:

In the name of Allah, most gracious, most Merciful; Praise be to God, the Sustainer of the Worlds; Merciful to all, compassionate to each; Lord of the day of judgement; You do we worship and to you we call for aid;

\footnotetext{
16 Ibid., 3-11.
}

17 Ibid., 17. 
Menurut Sardar, surat al-Fätihah:1-4 tersebut secara keseluruhan bertujuan untuk membangun makna dasar agama. Kata rabb dalam surat tersebut hendaknya dipahami sebagai Tuhan, yang berarti bahwa dialah Tuhan seluruh makhluk, bukan hanya Tuhan kaum muslim. ${ }^{18}$ Kemudian Sardar juga memahami kata 'álamin dengan mengatakan:

I prefer the common translation 'worlds' because it emphasises the plurality of creation. God's creation comes in different forms: Not just the conventional Muslim division of bumans, angels, and jinn, but also different races, cultures, religions and worldviews. Beyond the diversity of humanity there is the natural world, again in all its diversity of form, environments and eco-systems; and then there are worlds beyond our own terrestrial setting: the solar systems and galaxies of space, and of all these too, God is the Creator and Sustainer. This emphasis on plurality, especially I the sense that human diversity is an intentional and purposeful part of God's creation, is central to the message of the Qur'an. ${ }^{19}$

Lalu terkait dengan kata ar-rabmān:

Rahman has the meaning of a womb, as well as kinship, relationship, loving kindness, mercy and nourishing tenderness. What could be a more feminine attribute than a womb? It is the most ubiquitous reminder of the folly of thinking of god in simplistic gender terms. And the connotations coming from that derivation are indicative of the relationship of God to His creation. ${ }^{20}$

Pada penafsiran kata 'ālamin di atas, Sardar terlihat menghindari adanya monopoli satu 'ruang' makna. Sardar lebih memilih menafsirkan kata tersebut dengan alam yang beragam, meliputi seluruh alam semesta ciptaan Allah, tidak terbatas hanya yang ditempati manusia saja, seperti yang dipahami para mufassir mainstream. Sementara dari kata ar-rahmān, sardar menerjemahkannya dengan Yang Maha Pengasib terhadap semua. Konsekuensi dari penerjemahan tersebut, Ziauddin Sardar memahami bahwa sifat cinta dan kasih sayang Tuhan meliputi seluruh makhluknya.

Bahkan kasih sayang Tuhan meliputi orang-orang yang beriman maupun tidak, muslim ataupun kafir, dan yang tidak beragama sekalipun. Dalam penafsiran kata ar-Rahman di atas, Sardar juga mengajukan kritik sosial yang keras kepada orang-orang yang memahami tentang konsep "Tuhan" yang hanya dibatasi melalui istilah gender yang simplistis. Penafsiran Sardar tersebut dapat dikatakan 'berani' berbeda dengan penafsiran-penafsiran tradisional yang ada.

18 Lebih lanjut Ziauddin Sardar memahami kata rabb (Tuhan) sebagai yang Maha Suci berada di atas kategori gender dan semua kategori antromorfik lainnya. Tuhan tidak boleh diserupakan dengan manusia. Dalam Ibid., 64.

19 Ibid.

20 Ibid., 65. 
Ayat-ayat atau kosa kata tertentu yang dirasa tidak adil, maka Sardar menggunakan ijtihad nya agar dapat berlaku secara umum dan memenuhi rasa keadilan. ${ }^{21}$ Ini mengindikasikan pemikiran-pemikiran Sardar yang dapat dimasukkan sebagai pemikir progresif. Untuk mendukung argumen tersebut, akan dipaparkan lebih lanjut tentang contoh-contoh penafsiran Sardar dengan berbagai model penafsirannya.

Kaitannya dengan Surat al-Fatihah, Sardar kemudian melanjutkan penafsiran surat tersebut pada bagian kedua ini:

Guide us to the straight way, The path of those on whom your grace abounds, Not those on whom your anger falls, nor those who go astray. ${ }^{22}$

Ziauddin Sardar melihat fokus Surat al-Fatihah bagian kedua (ayat 5-7) ini tentang Jalan yang Lurus. Menurutnya, Jalan yang Lurus bukanlah tujuan, tetapi alat navigasi untuk menempuh perjalanan. Tidak ada jaminan setiap orang dapat menggapainya, sekalipun mereka adalah seorang mukmin yang saleh. ${ }^{23}$ Penafsiran sardar tersebut jika dibaca pada saat ini sangat relevan.

Dimana saat ini marak berkembang truth claim, monopoli kebenaran hanya milik kelompoknya, justifikasi dalam perbedaan, dan lain-lain. Yang mana muara akhirnya adalah munculnya kasus-kasus kekerasan atas nama agama. Teks (al-Qur'an dan hadis) hanya dijadikan kedok semata untuk melancarkan aksi-aksi persekusi dan kekerasan terhadap yang 'berbeda'. ${ }^{24}$

Walaupun penafsirannya ini disajikan sederhana, akan tetapi berdasarkan pemaparan penjelasan di atas menunjukkan muatan pesan moralnya begitu kuat. Dikatakan sederhana karena Sardar dalam penafsiran al-Qur'annya ini sama sekali tidak menggunakan tulisan asli ayat-ayat al-Qur'an yang menggunakan bahasa arab. Seperti yang telah dijelaskan, Sardar hanya mencukupkan dengan menulis terjemahannya saja, lalu dilanjutkan dengan menuliskan penafsirannya.

${ }^{21}$ Seperti yang telah dipaparkan pada contoh penafsiran di atas, bahwa Sardar mengkritik keras beberapa penafsiran yang menggambarkan "Tuhan" dengan istilah gender yang simplistis. Lihat Ibid.

22 Ibid., 67.

23 Sardar mengungkapkan bahwa mengikuti jalan yang lurus tidak berarti memiliki jawaban tunggal yang diterapkan setiap keadaan. Yang dapat dilakukan oleh manusia yang lemah dan tak luput dari dosa ialah melakukan yang terbaik sesuai dengan kemampuannya. Dalam Ibid., 70.

${ }^{24}$ Di Indonesia sendiri pada masa kini cukup sering ditemui 'pembacaan' tidak utuh terhadap hadis-hadis yang justru menuai polemik. Lihat Taufan Anggoro, "Perkembangan Pemahaman Hadis di Indonesia: Analisis Pergeseran dan Tawaran di Masa Kini”, Jumal Diya' al-Afkear 7, no. 1 (Juni 2019): 161-162, doi: 10.24235/diyaafkar.v7i01.4533. 
Hal yang sama juga ditempuh Sardar dalam menafsirkan surat berikutnya, yaitu Surat al-Baqarah. ${ }^{25}$ Dengan membagi surat tersebut menjadi beberapa bagian, lalu menentukan isi pokoknya yang dibahas dalam kumpulan ayat tersebut. Dapat dikatakan bahwa Ziauddin Sardar dalam tafsirnya tersebut fokus pada penyampaian pesan moral. Pesan moral sangat kuat dalam tafsir tersebut, dari pada eksplorasi internal teks, seperti yang dilakukan oleh para mufassir klasik pada umumnya.

Kemudian, model kedua tafsir tematik Ziauddin Sardar ialah dengan menyusun ayat-ayat al-Qur'an berdasarkan tema atau topik-topik tertentu. Berikut contoh penafsiran yang dilakukan Sardar dalam model ini:

Dalam membahas topik Akal dan Pengetabuan, Sardar mengumpulkan beberapa ayat al-Qur'an yang relevan. Dengan berpijak pada Surat al-Jatsiyah:5, Sardar berpendapat bahwa akal merupakan sarana untuk menggapai iman, alat penemuan, dan perangkat untuk mendekatkan diri kepada Tuhan. ${ }^{26}$ Dalam proses tersebut, manusia diperintahkan untuk menggunakan akal/rasio dan pendengarannya. ${ }^{27}$

Penggunaan akal disini merupakan suatu proses mengemukakan pendapat, saling tukar pikiran, saling menyanggah, saling apresiasi, dan lain-lain. Sardar dalam penjelasannya ini ingin mengambil substansi penting dari sebuah proses "diskusi". Menurut Sardar, al-Qur'an menekankan manusia untuk mendapatkan pengetahuan sejati dengan saling berdialog dan mendengarkan argumen-argumen berupa kritik, otokritik, dan kontra kritik.

Sardar dalam kesempatan ini juga turut melontarkan kritik yang ditujukan kepada ulama yang menyalahgunakan otoritas keagamaannya dalam hal penafsiran agama. ${ }^{28} \mathrm{Hal}$ ini menunjukkan bahwa ilmu pengetahuan harus selalu dikembangkan dengan seluruh daya akal yang dimiliki, dan senantiasa mengedepankan sikap kritis. Penafsiran Sardar terkait tema Akal dan Pengetabuan

${ }^{25}$ Dalam menafsirkan Surat al-Baqarah, Sardar membaginya menjadi 19 bagian. Setiap bagian tersebut diberi suatu kalimat kunci yang menggambarkan isi kumpulan beberapa ayat secara umum.

26 Ziauddin Sardar, Reading the Qur'an, 251.

27 Dengan mengutip Surat al-Mulk: 10, Sardar melihat bahwa "akal/rasio" dan pendengaran disebut secara berdampingan karena setiap argument penalaran mempunyai kontra-argumen. Pemahaman datang tidak hanya dari penalaran semata, tetapi juga dari munculnya argument balasan (kontra-argumen). Hal ini menjelaskan pentingnya sebuah diskusi, sehingga seseorang selalu mempunyai pertimbangan dalam proses penalarannya. Dalam Ibid., 252.

28 Berdasarkan Surat az-Zukhruf: 22-23 dan al-Isrä: 36 Ziauddin Sardar mengatakan jika Iman hanya dapat dijelaskan dan diajarkan oleh Ulama maka bertentangan dengan pesan al-Qur'an. Upaya membatasi tersebut disinyalir sebagai siasat dari kelompok ulama untuk mengendalikan pemikiran dan penafsiran agama. Sesungguhnya, pengetahuan bukan milik segelintir orang saja. Dalam Ibid. 
ini ditutup dengan menghubungkannya dengan penjelasan Surat az-Zumar: 9 yang membicarakan tentang esensi penggunaan akal.

Menurutnya, al-Qur'an memberi tempat terbaik bagi orang-orang yang mau menggunakan akalnya untuk ilmu pengetahuan. Bukan menganggap Iman hal yang tak penting, akan tetapi Sardar melihat bahwa wilayah Iman yang digambarkan oleh al-Qur'an bersifat rasional dengan berbagai sudut pandang yang diambil, baik itu oleh umat Islam sendiri maupun pemeluk agama lain, atau bahkan orang yang tidak beragama sekalipun. ${ }^{29}$

Dari penafsiran tentang tema tersebut, terlihat bagaimana semangat berfikir yang hendak dikampanyekan oleh Sardar dalam koridor umat beragama (Iman). Semangat berfikir Sardar tersebut bukan menafikan begitu saja keyakinan (Iman), tetapi justru menggunakan rasio untuk memperkuat keyakinan (Iman) agar mampu membebaskan manusia dari pengaruh irrasional (mistik), fanatisme, dan taklid buta. Kesimpulan tersebut diperoleh Sardar melalui pengamatannya terhadap ayat-ayat al-Qur'an yang berisi tentang perintah berfikir, yang menurutnya jumlahnya cukup banyak.

\section{Menggali Konteks Sosio-Historis}

Dalam menfsirkan al-Qur'an, Ziauddin Sardar turut melibatkan konteks historis yang melatarbelakangi turunnya ayat-ayat al-Qur'an. Hal ini dapat ditunjukkan pada beberapa penafsirannya, seperti ketika dia membahas topik Poligami dalam Surat an-Nisa : 3 misalnya. Sardar mengatakan bahwa sebenarnya ayat tersebut secara khusus memfokuskan berbicara tentang anak yatim, bukan tentang ijin melakukan poligami.

Ketika masa-masa permulaan hijrah, Rasulullah SAW mengalami dua kali peperangan besar melawan pasukan Quraisy. Dengan adanya dua perang besar tersebut menimbulkan korban, yang mengakibatkan banyaknya anak-anak yang kehilangan ayahnya sehingga menjadi anak yatim. Lalu anak-anak yatim ini ternyata kondisinya menjadi sedikit terabaikan, karena tidak dirawat dengan baik. Diantara anak-anak yatim tersebut adalah perempuan, sehingga umat Muslim Madinah saat itu bersikeras kepada Nabi SAW untuk menikahi anak-anak yatim perempuan tersebut. ${ }^{30}$

Sardar menambahkan bahwa pada Surat an-Nisāa: 3 terdapat kontradiksi. Dimana laki-laki dibolehkan menikah dengan beberapa perempuan, tetapi di sisi lain juga diharuskan berbuat adil kepada para istrinya. ${ }^{31}$ Penafsiran Sardar

29 Ibid., 253.

${ }^{30} \mathrm{Hal}$ ini ditambah dengan situasi makro Madinah saat itu, dimana laki-laki memiliki banyak istri sudah menjadi kelaziman. Lihat Ibid., 306.

31 Menurut Sardar, kontradiksi yang terdapat dalam ayat ini bertujuan kreatif, jadi umat beriman diharuskan merenungkan hasrat mereka untuk memiliki istri banyak 
tersebut berbeda dengan penafsiran klasik mainstream, yang lebih memahaminya sebagai kebolehan melakukan poligami.

Ini menunjukkan kejelian Sardar dalam memahami suatu ayat, sehingga dapat membedakan mana makna al-Qur'an yang menjadi pesan pokok, dan yang bukan. Penentuan makna pokok al-Qur'an di atas memberi dampak yang cukup signifikan dalam penafsiran. Karenanya, melibatkan konteks historis dalam menafsirkan al-Qur'an ini sangat penting, dimana lokalitas dan universalitas pesan al-Qur'an dapat diketahui.

Prinsip inilah yang dipegang secara teguh oleh Sardar, seperti terlihat dalam contoh penafsiran berikutnya yang juga menggali aspek konteks historis. Di bawah ini merupakan pemaparan konteks historis dalam penafsiran Sardar tentang makna Hijab dalam al-Qur'an:

Ayat-ayat yang berbicara mengenai bijab dalam al-Qur'an terdapat dalam QS. Maryam: 17; Sad: 32; al-Isrä': 45; Fushshilat. 5; asy-Syura': 51; al-A'räf: 46; alAbräb: 53; dan al-Mutaffifin: 15. Ketika mencermati ayat-ayat tersebut, Ziauddin Sardar mengemukakan beberapa hal terkait situasi dan kondisi yang mengitarinya: Pertama, masyarakat Madinah saat itu terkenal sangat akrab dan terbatas. Sedangkan rumah Rasulullah sendiri tidak banyak memiliki ruang pribadi, sehingga perbedaan antara kehidupan privat dan publik Nabi sudah hilang. ${ }^{32}$

Kedua, ada satu ayat khusus yang turun berkenaan ketika Rasulullah baru saja menikahi Zainab binti Jahsy, lalu mengundang tamu-tamu ke pernikahan beliau. Kemudian ada tiga orang tamu yang berkunjung terlalu lama dan tidak segera bersedia pulang dari rumah Nabi. Padahal, sebagai pasangan yang baru menikah, Rasulullah tentu ingin berduaan dengan istrinya tersebut, sehingga berkali-kali Rasulullah sampai meninggalkan tamu tersebut. Ketika tamu-tamu tersebut pergi, pembantu Rasulullah, yaitu Anas bin Malik ingin berbicara dengan Nabi. Lalu akhirnya Rasulullah membuat tirai sebagai pembatas antara beliau dengan Anas bin Malik. Pada momen inilah turun ayat al-Qur'an yang berkaitan dengan bijab sebagai pembatas..$^{33}$

Kemudian yang ketiga, Sardar melihat bahwa gaya berpakaian kaum wanita Madinah saat itu banyak mengungkap tubuh. Busana yang dikenakan

dan menuntut mereka (para suami) agar berlaku adil. Berdasarkan konteks historis ayat tersebut, Ziauddin Sardar menilai ayat-ayat tentang poligami ini bermaksud untuk mentransformasikan masyarakat Arab saat itu. Yaitu mengubah masyarakat poligamis menjadi masyarakat monogamis. Lihat Ibid.

32 Selain itu, pusat perhatian kaum Muslim yang baru berkembang tidak hanya Rasulullah, tetapi juga para istri Rasulullah sendiri. Musuh-musuh Rasulullah mengancam dengan mengumumkan niat mereka untuk menikahi istri-istri Nabi setelah beliau wafat. Dalam Ibid., 331.

33 Ibid. 
kaum perempuan saat itu memiliki lekukan lebar yang mengungkap buah dada. ${ }^{34}$ Setelah memaparkan beberapa konteks historis ayat-ayat tentang hijab tersebut, Sardar menilai tidak ada tuntutan hukum baik al-Qur'an maupun hadis yang mewajibkan wanita muslim untuk mengenakan bijab (dalam arti burqa, chador, abaya, atau niqab). ${ }^{35}$

Dapat disimpulkan bahwa penafsiran Sardar terkait tema hijab ini membedakan hijab ke dalam dua makna. Pada pemaparan konteks pertama dan kedua di atas, Sardar mengaitkan makna hijab sebagai "Pembatas", sedangkan yang ketiga, memaknainya sebagai kain yang menyelimuti tubuh wanita (kerudung, jilbab, dan lain-lain). Dari penjelasan di atas secara umum menunjukkan bahwa Ziauddin Sardar menaruh perhatian yang lebih pada aspek konteks dalam menafsirkan al-Qur'an.

Bahkan tak jarang Sardar ketika sudah mengungkapkan konteks yang mengitarinya, langsung memaparkan makna yang terkandung menurut apa yang dipahaminya. Selain itu, dari paparan penjelasan di atas menunjukkan bahwa Sardar membagi dua jenis konteks historis dalam menafsirkan al-Qur'an, yaitu konteks khusus (yang bersinggungan langsung dengan Rasulullah), dan konteks umum yang berkaitan dengan sosial kemasyarakatan Arab saat itu.

\section{Menggali Makna ayat-ayat al-Qur'an yang Signifikan (Makna Substantif)}

Dalam menafsirkan ayat-ayat al-Qur'an, Ziauddin Sardar tidak terkungkung pada teks ayat Qur'an semata, tetapi juga berupaya menangkap makna tersirat yang terkandung di dalamnya. Makna tersirat yang dimaksud disini adalah makna yang signifikan, yang menjadi pokok ayat-ayat al-Qur'an. Beberapa pemikir muslim progresif juga menaruh perhatian terhadap makna signifikan ini, walaupun dengan sebutan yang berbeda-beda. ${ }^{36}$

Signifikansi ayat al-Qur'an disini menjadi penting, karena melalui jalan inilah al-Qur'an dapat berlaku secara universal. Jargon al-Qur'an shalib li kulli zaman wa makan akan dapat terwujud apabila sang penafsir mampu menemukan makna yang signifikan dalam ayat-ayat al-Qur'an. Dalam penafsiran alQur'annya ini, Sardar selalu berupaya untuk menemukan makna yang signifikan dalam ayat-ayat al-Qur'an. Hal ini dapat ditemukan ketika Sardar menafsirkan tentang konsep Ummah.

34 Ibid., 332.

${ }^{35}$ Hijab adalah masalah pribadi bagi setiap perempuan, yang mana pilihan ini bergantung pada kebudayaan, kondisi sosial, dan realitas sejarah. Dalam Ibid., 334-335.

36 Misalnya Fazlur Rahman menyebutnya dengan ideal-moral, Nashr Hamid Abu Zayd dengan maghza, Jasser Auda dengan Maqashid, dan lain-lain. 
Dengan berpijak pada Surat al-Mujāiliab: 7, Sardar melihat bahwa Ummah merupakan konsep moral yang berarti suatu komunitas, bukan sebuah entitas monolitik ataupun sebuah istilah (yang berasosiasi negatif) yang dipakai untuk men-judge kelompok lain yang berbeda. ${ }^{37}$ Penafsiran Sardar melalui penemuan makna yang signifikan tersebut memang sedikit 'menyimpang' dari mufassir klasik, yang lebih mengidentikkan konsep Ummah dengan suatu entitas monolitik.

Kemudian, dilanjutkan dengan membaca Surat Áli Imrän: 110; alHujurät: 10; at-Taubah: 71; dan as-Saff: 4, Sardar menafsirkan konsep Ummah dengan suatu komunitas yang memiliki tujuan moral yang sama di dalam keanekaragaman semua kelompok penyusunnya. ${ }^{38}$ Selain mengenai konsep Ummah ini, penafsiran Sardar dengan menggali makna al-Qur'an yang signifikan dapat ditemui ketika menafsirkan kata khalifah. Sardar menafsirkan kata khalifah sebagai pemegang mandat dari Tuhan, atau pemegang perwalian. ${ }^{39}$

Tentu penafsiran Sardar ini sedikit berbeda dengan beberapa mufassir yang memahami kata khalifah sebagai pemimpin. Lalu, sejauh apa implikasi dari penggalian atas signifikansi ayat al-Qur'an terkait konsep khalifah tersebut? Ziauddin Sardar melihat bahwa jika kata khalifah dipahami sebagai "Pemegang Mandat" maka dia tidak memiliki hak eksklusif atas apapun. Pemahaman tersebut justru bermakna sebaliknya jika khalifah dipahami sebagai "pemimpin", yang lebih dekat dengan kehidupan glamour dan eksklusif. ${ }^{40}$

Sardar menegaskan bahwa tugas khalifah sejatinya adalah melaksanakan tanggung jawabnya secara benar dan memastikan aset perwalian bertahan dan berkembang. ${ }^{41}$ Terlihat bagaimana implikasi jika penafsiran al-Qur'an turut mengeksplorasi makna yang signifikan dan yang tidak, memang sangat jauh berbeda. Dan tentu ini menjadi suatu kekhasan tersendiri dari pendekatan kontekstual dalam menafsirkan al-Qur'an, karena penggalian terhadap substansi makna menjadi sangat penting.

Langkah Sardar dalam menemukan signifikansi makna al-Qur'an tersebut sejalan dengan apa yang dilakukan oleh Fazlur Rahman. Walaupun dengan proses yang sedikit berbeda. ${ }^{42}$ Dalam penafsirannya tersebut, Sardar

37 Dalam Ziauddin Sardar, Reading the Qur'an, 245-246.

38 Sebagai konsep maupun praktik, Ummah ingin menunjukkan keberagaman atau keanekaragaman dalam kemanunggalan. Lihat Ibid., 246.

${ }^{39}$ Ibid., 266.

40 Ibid.

41 Ibid., 267.

${ }^{42}$ Dalam pemikiran tafsir Fazlur Rahman, istilah ini dinamakan dengan Tllat alHukm (ratio legis). Melalui penggalian Tlat al-Hukm inilah yang kemudian melahirkan istilah moral ideal (ideal moral). Ideal moral merupakan penjabaran dari prinsip-prinsip umum dan ajakan-ajakan moral al-Qur'an yang berfungsi sebagai ajaran dasar al-Qur'an. 
turut mengemukakan kritik sosialnya terhadap makna khalifah yang saat ini sangat dekat dengan kehidupan eksklusif dan mewah. Dia mengecam jenis pemimpin tersebut sambil menekankan bahwa makna pemimpin lebih identik pada beban kuasa dan tanggung jawab mengurus kepentingan publik.

\section{Tafsir Tematik-Kontekstual Ziaudin Sardar dalam Khazanah Hermeneutika al-Qur'an}

\section{Kerangka Interpretasi Tematik-Kontekstual Ziauddin Sardar}

Ziauddin Sardar meyakini bahwa al-Qur'an adalah awal dan sumber moralitas. ${ }^{43}$ Argumen tersebut berbeda dengan apa yang dianut oleh beberapa ulama klasik, yang meyakini bahwa moralitas berujung pada al-Qur'an. Hal tersebut sudah menjadi prinsip Sardar ketika menafsirkan al-Qur'an, yang ingin mengambil 'langkah' yang berbeda dari para mufassir klasik.

Untuk mengetahui lebih jelas bagaimana langkah yang diambil Sardar ketika menafsirkan al-Qur'an, dapat dilihat pada bagan berikut:

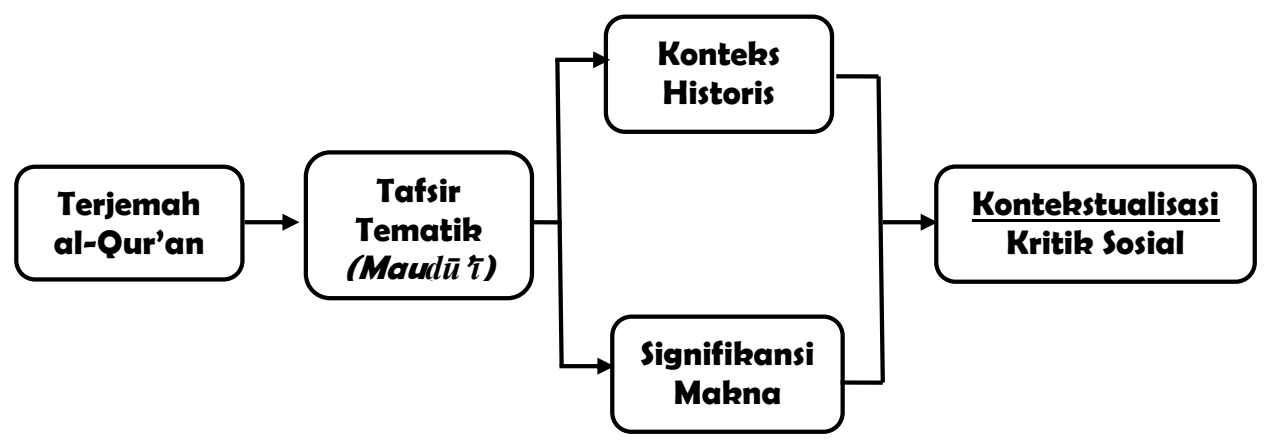

Ziauddin Sardar ketika berinteraksi dengan al-Qur'an selalu menggunakan terjemahan sebagai alat bantu memahami al-Qur'an. Menurutnya, terjemah al-Qur'an dapat membuka pemahaman pembaca untuk mengetahui makna dasar al-Qur'an. Namun, Sardar tidak sembarang dalam memilih terjemah al-Qur'an yang dipakai dalam menafsirkan Qur'an ini. ${ }^{44}$ Sardar

Dalam Ilyas Supena, Hermeneutika al-Qur'an dalam Pandangan Fazlur Rabman (Yogyakarta: Ombak, 2014), 88-89.

${ }^{43}$ Moralitas al-Qur'an bukan titik akhir pemikiran dan evolusi manusia. AlQur'an merupakan sumber dan landasan yang menopang gerak pemikiran dan perkembangan moralitas. Dalam Ziauddin Sardar, Reading The Qur'an, 20.

44 Faktor lain yang mendorong Ziauddin Sardar untuk menggunakan terjemah al-Qur'an karena dirinya mengakui secara sadar kurang menguasai Bahasa Arab. Lihat Ibid., xvii. 
memakai enam karya terjemahan al-Qur'an yang telah dipilihnya, lalu membaca terjemahan tersebut ayat demi ayat dan memilih bahasa yang paling jelas, sambil menyisihkan gaya bahasa yang dianggap kuno. ${ }^{45}$

Perlu menjadi perhatian pada tahap ini, yang berkaitan dengan penggunaan terjemah al-Qur'an dalam penafsiran Ziauddin Sardar tersebut. Terjemah al-Qur'an yang digunakan oleh Sardar berfungsi untuk mengetahui pesan umum yang terkandung dalam suatu ayat, sehingga Sardar tidak melakukan analisis teks al-Qur'an secara memadai. Walaupun hanya mendudukkan terjemah pada fungsi tersebut, penafsiran yang dihasilkan akan kehilangan banyak dimensi teks yang sangat fundamental.46

Setelah melalui tahap pengkajian terhadap terjemah al-Qur'an, Sardar melakukan penafsiran secara tematik (maud $\tilde{u}^{\prime}$ ) baik berdasarkan tema-tema, maupun berdasarkan tematik surat. Dalam menafsirkan al-Qur'an secara tematik ini, Sardar juga melibatkan konteks historis turunnya ayat-ayat al-Qur'an. Ini sesuai dengan prinsip penafsiran kontekstual, yang mana tidak hanya bertumpu pada makna lahir teks saja, tetapi juga melihat aspek sosio-historis dimana, kapan, dan mengapa suatu ayat diturunkan. ${ }^{47}$

Proses tersebut erat kaitannya dengan langkah berikutnya, yaitu pencarian makna yang substantif (signifikansi makna al-Qur'an). Dengan melihat konteks sosio-historis saat turunnya al-Qur'an, lalu membaca situasi dan kondisi masa kini maka akan didapat makna substantif al-Qur'an tersebut. Setelah makna substantif diperoleh, selanjutnya ialah mencari relevansi al-Qur'an di masa kini yang dalam hal ini dikenal istilah kontekstualisasi al-Qur'an.

Dalam melakukan kontekstualisasi tersebut, Sardar menekankan pentingnya membaca secara kritis-argumentatif. Karena baginya, al-Qur'an harus didekati melalui pertanyaan dan argumen. ${ }^{48}$ Sedangkan kritis disini adalah nilainilai moralitas yang ada dalam al-Qur'an mampu menjadi kritik sosial bagi kehidupan umat manusia. Dengan demikian dapat diketahui beberapa unsur

${ }^{45}$ Beberapa referensi terjemah al-Qur'an yang dipakai Sardar ialah: Pertama, The Message of The Qur'an karya Muhammad Asad; Kedua, The Qur'an: A New Translation karya MAS. Abdel Haleem; Ketiga, The Qur'an: A New Translation karya Thariq Khalidi; Keempat, The Koran Interpreted karya A.J. Arberry; Kelima, The Meaning of The Glorious Koran karya M.M. Pickthall; dan Keenam, The Holy Qur'an karya Yusuf Ali. Dalam Ibid., 110 115.

${ }^{46}$ M. Solahudin, "Pendekatan Tekstual dan Kontekstual dalam Penafsiran alQur'an”, Jurnal al-Bayan 1, no. 2 (Desember 2016): 119, doi:10.15575/albayan.v1i2.1596.

47 Muhammad Hasbiyallah, "Paradigma Tafsir Kontekstual: Upaya Membumikan Nilai-Nilai al-Qur'an”, Jurnal adz-Drikera 12, no. 1 (Januari 2018): 34, doi:10.24042/al-dzikra.v12i1.2924.

${ }^{48}$ Lihat Ziauddin Sardar, Reading The Qur'an, 22. 
penting dalam penafsiran Sardar ini, diantaranya Terjemah al-Qur'an, Tafsir tematik, konteks historis, makna substantif, dan kontekstualisasi.

\section{Tinjauan Hermeneutis Interpretasi Tematik-Kontekstual Ziauddin Sardar}

Dalam bidang keilmuan penafsiran moderen (hermeneutika) terdapat beberapa aliran, seperti aliran obyektifis, subyektifis, dan obyektifis cum subyektifis. ${ }^{49}$ Jika menggunakan kacamata tipologi tersebut, maka Ziauddin Sardar dapat dimasukkan kedalam aliran obyektifis cum subyektifis. Sardar lebih banyak membahas aspek konteks dalam memahami ayat-ayat al-Qur'an. Oleh karena itu, Sardar lebih mendukung interpretasi yang menekankan aspek text-reader. Karena dengan berpijak pada aspek text-reader, esensi tugas penafsir untuk menemukan relevansi al-Qur'an di masa kini akan tercapai.

Sedangkan analisis kebahasaan dalam ayat-ayat al-Qur'an justru kurang mendapat perhatian darinya. Ini dikarenakan Ziauddin Sardar sendiri dari sisi background pendidikan lebih banyak pada bidang sains, sehingga kurang menguasai Bahasa Arab. Dan dapat dilihat dalam penafsirannya aspek teks kurang dielaborasi secara komprehensif dalam penafsirannya. ${ }^{50}$ Namun, bentukbentuk operasi hermeneutik telah nampak dalam penafsirannya, dengan lebih 'membidik' aspek konteks dan kontekstualisasi al-Qur'an.

Hal tersebut sejalan dengan kritikannya pada model-model penafsiran alQur'an yang hanya mementingkan aspek text-author. Walaupun begitu, Sardar juga tidak secara otomatis menekankan obyektifitas secara mutlak. Tidak pula menekankan subyektifitas, dimana penafsir (reader) dapat menentukan makna alQur'an sesuai keinginannya sendiri. Namun, Sardar melalui perantara kritik sosial yang ditambahkan dalam setiap penafsirannya juga menampakkan subyektifitasnya. ${ }^{51}$

49 Pertama, aliran obyektifis ialah aliran yang lebih menekankan pada pencarian makna asal dari obyek penafsiran. Kedua, aliran subyektifis merupakan aliran yang lebih menekankan pada peran pembaca/penafsir dalam memahami teks. Dan ketiga, aliran obyektifis cum subyektifis adalah aliran yang berada di tengah-tengah kedua aliran tersebut. Dalam Sahiron Syamsuddin, Hermeneutika dan Pengembangan Ulumul Qur'an (Yogyakarta: Nawesea Press, 2009), 26.

50 Hanya beberapa bagian saja Sardar memaparkan analisis teks dalam penafsirannya. Misalnya ketika dia menafsirkan kata dharaba. Itupun hanya dipahami Sardar sebatas sebuah kata yang mengandung banyak kemungkinan makna dalam alQur'an. Dalam Ziauddin Sardar, Reading The Qur'an, 307.

${ }^{51}$ Kritik sosial yang disampaikan Sardar cukup banyak ditemui, misalnya dalam tema Kemanusiaan dan Keberagamaan. Sardar memandang bahwa pluralisme relevan dalam suatu masa ketika dasar identitas melemah. Kita sering bicara tentang identitas majemuk 
Berdasarkan beberapa argumen tersebut kiranya sesuai, jika dikatakan bahwa 'posisi' Sardar memang berada diantara aliran subyektifitas dan obyektifitas. ${ }^{52}$ Bahwa terdapat subyektifitas dalam menafsirkan, Sardar tidak dapat memungkirinya. Dimasukkannya Sardar dalam tipologi tersebut sejalan dengan Lien Iffah Nafatu Fina yang memasukkan Abdullah Saeed dalam tipologi tersebut. ${ }^{53}$

Dikaitkannya tokoh pemikir Abdullah Saeed dalam pembahasan ini karena mempunyai hubungan keilmuan dengan Ziauddin Sardar. Berdasarkan kajian yang telah dilakukan, penulis melihat bahwa Ziauddin Sardar sedikit banyak telah terpengaruh dengan pemikiran Abdullah Saeed, khususnya dalam bidang tafsir al-Qur’an. Jika dirunut lebih jauh lagi, pemikiran Sardar dalam hal penafsiran al-Qur'an juga mendapat pengaruh dari Fazlur Rahman.

Bahkan yang paling dominan mempengaruhi pemikiran tafsir Sardar ini adalah Fazlur Rahman, karena penggalian terhadap konteks sosio-historis dan makna al-Qur'an yang signifikan sangat menonjol dalam penafsirannya ini.

Argumen tersebut didukung dengan penelitian lain yang juga menyatakan adanya pengaruh pemikiran Fazlur Rahman dalam penafsiran yang dilakukan oleh Sardar. ${ }^{54}$ Selain Abdullah Saeed dan Fazlur Rahman, tokoh lain yang juga mempengaruhi penafsiran Ziauddin Sardar ini ialah Farid Esack. Farid Esack populer dengan tawaran hermeneutik al-Qur'annya yang berpijak pada pembebasan dan persamaan dengan mempertimbangkan aspek kontekstual di mana ia hidup..$^{55}$

Dari penelitian yang telah dilakukan ini, pemikiran Sardar mendapat pengaruh dari Farid Esack dalam hal kontekstualisasi. Kontekstualisasi yang dimaksud adalah pada coraknya, yang lebih mengarahkan pada argumen kritik

dan minoritas etnis, tetapi justru kita sendiri tidak yakin bagaimana seharusnya hidup bersama sambil mempertahankan identitas yang khas dan berbeda. Lihat Ibid., 210.

52 Ini didukung dengan pernyataan Ziauddin Sardar yang mengatakan bahwa manusia hanya dapat mengkaji al-Qur'an dan menafsirkannya menurut perspektif kontemporer mereka sendiri. Al-Qur'an harus dikembangkan dalam lingkup kehidupan dan peradaban yang terus berkembang. Seorang penafsir harus bebas dari berbagai kepentingan ketika akan menafsirkan Qur'an. Selain itu, kerja penafsir juga penting untuk tidak mengabaikan penggalian konteks historis untuk mendapatkan makna sejati al-Qur'an. Lihat Ibid., 27-28.

53 Lien Iffah Nafatu Fina, "Interpretasi Kontekstual: Studi Pemikiran Hermeneutika al-Qur'an Abdulah Saeed” , Jurnal Esensia XII, no. 1 (Januari 2011): 173, doi:10.14421/esensia.v12i1.707.

54 Adi Fadilah \& Kusmana, “Ziauddin Sardar's Interpretation of the Qur'an”, Jurnal Education and Humanities Research (ASSEHR) 137, (Januari 2018): 321, doi:http://10.2991/icqhs-17.2018.48.

55 M. Solahudin, "Pendekatan Tekstual dan Kontekstual", 120. 
sosial. ${ }^{56} \mathrm{Hal}$ ini tentu sejalan dengan model hermeneutik Farid Esack yang dikenal sebagai "Hermeneutika Pembebasan". ${ }^{57}$ Beberapa karya dari ketiga pemikir tersebut juga sama-sama dijadikan Sardar sebagai referensi pokok dalam tafsir tematiknya ini.

Dalam kaitannya posisi antar tokoh, masing-masing mempunyai kekhasan secara metodologis. Baik Saeed maupun Sardar sama-sama sebagai pelanjut teori double movement Fazlur Rahman. Hal ini dapat dilihat dalam contoh penafsiran Sardar yang telah dipaparkan, betapa penggalian terhadap konteks historis dan pembacaan masa kini sangat menonjol. Jika Rahman lebih condong kepada aspek ideal moral dan Saeed fokus pada etik hukum, maka Sardar menggabungkan kedua unsur tersebut dalam penafsirannya.

Menyangkut kedua unsur tersebut, Sardar mengatakan bahwa ketika menafsirkan al-Qur'an, perlu ada pembedaan yang tegas mana tuntutan hukum dan mana perintah moral. Namun perlu diingat, pembedaan secara tegas disini bukan untuk menafikan satu sama lain. ${ }^{58}$ Walaupun demikian, penulis melihat sisi metodologi penafsiran al-Qur'an Ziauddin Sardar dalam tafsirnya ini kurang begitu sistematis dan komprehensif, jika dibandingkan dengan Fazlur Rahman dan Abdulah Saeed.

Hal tersebut disebabkan karena Sardar lebih banyak bergelut dalam ranah praktis penafsiran, dibandingkan dalam hal diskusi metodologinya. Dalam khazanah penafsiran kontekstual yang perlu diperhatikan adalah mencermati

${ }^{56}$ Contoh kontekstualisasi yang menampilkan kritik sosial disini misalnya ketika Sardar menafsirkan tentang topik Kemurtadan dan Hijrah. Menurutnya, saat ini muncul sekelompok pemuka agama populis yang selalu merasa benar. Mereka orang yang tak pernah bosan dan penuh obsesi bicara tentang Tuhan, meneriakkan keimanan mereka kepada-Nya, dan melantunkan zikir di setiap kesempatan. Namun kenyataannya, di sisi lain mereka tidak melakukan apa-apa selain hanya menyebar kerusakan dengan ceramah-ceramah yang penuh kemarahan dan hasutan. Mereka dipandu oleh keangkuhan dan kesombongan mereka. Lihat Ziauddin Sardar, Reading The Qur'an, 157.

57 Teologi Pembebasan lahir dan berkembang di Amerika Latin sebagai sebuah gerakan pemerdekaan bagi kelompok masyarakat miskin, pinggiran, dan tertindas. Teologi pembebasan tampil dengan menyerukan persamaan hak tanpa memandang latar belakang, agama, etnis, dan warna kulit. Di kalangan Islam, Farid Esack (pemikir dari Afrika Selatan) adalah salah seorang yang dengan sangat semangat mendengungkan pembebasan. Dalam Sudarman, "Pemikiran Farid Esack tentang Hermeneutika alQur'an” , Jumal al-Adyan X, no. 1 (Januari 2015): 84, doi: https://doi.org/10.24042/ajsla.v10i1.1424.

58 Dalam Ziauddin Sardar, Reading The Qur'an, 372. 
relasi antara teks, penafsir dan realitas (konteks). Akan tetapi, tidak semata hanya fokus kepada makna literal teks semata..$^{59}$

Ziauddin Sardar (dengan segala kekurangan dalam penafsirannya) bagaimanapun perlu diapresiasi atas kerjanya dalam memperkaya khazanah Tafsir Kontekstual. Penafsiran melalui argumen kritisnya sangat relevan dengan masa kini, dimana saat ini masuk pada sebuah era yaitu era disrupsi. Isu-isu atau topik yang diangkat Sardar juga sangat mengena, dimana sikap 'monopoli kebenaran' masa kini sedang menjamur, baik di dunia offline maupun online.

Belum lagi problem-problem kemanusiaan lain yang juga tidak lepas dari 'sasaran tembak' Sardar dalam tafsirnya. Oleh karena itu, karya Ziauddin Sardar yang berjudul Reading The Qur'an ini kiranya muncul di momen yang tepat. Sebuah tafsir bercorak kritis yang penulis sebut sebagai social criticism in interpretation (kritik sosial dalam penafsiran al-Qur'an). Kedepan, perlu ada penelitian yang mengkaji secara khusus model kontekstualisasi Sardar tersebut, atau bahkan komparasi dengan model kontekstualisasi tokoh-tokoh lainnya.

\section{Kesimpulan}

Sardar melakukan penafsiran secara tematik (maud̄̄î) baik berdasarkan tema-tema, maupun berdasarkan tematik surat. Dalam menafsirkan al-Qur'an ini, Sardar menganut prinsip penafsiran kontekstual, dengan melihat konteks sosio-historis al-Qur'an, lalu membaca situasi dan kondisi masa kini, sehingga didapatkan makna substantif al-Qur'an. Setelah makna substantif diperoleh, selanjutnya ialah mencari relevansi al-Qur'an di masa kini yang dalam hal ini dikenal istilah kontekstualisasi al-Qur'an. Bentuk-bentuk operasi hermeneutik telah nampak dalam penafsiran Sardar, dengan lebih 'membidik' aspek konteks dan kontekstualisasi al-Qur'an. Adapun aspek teks kurang digali secara mendalam oleh Sardar, karena keterbatasan kemampuannya dalam berbahasa arab.

Dalam penafsiran tematik-kontekstual Ziauddin Sardar ini yang paling dominan mempengaruhi metodologi penafsirannya ialah teori double movement Fazlur Rahman, dan yang kedua adalah teori ethico legal Abdullah Saeed. Sedangkan dalam hal kontekstualisasi al-Qur'annya, corak "Hermeneutika Pembebasan" Farid Esack sangat terasa dalam tafsir Ziauddin Sardar tersebut. Ini menyebabkan penafsiran al-Qur'an yang dilakukan oleh Sardar sarat akan nuansa kritis lewat kritik-kritik sosial yang diungkapkannya. Oleh karena itu, tafsir tematik-kontekstual Sardar dapat disebut sebagai social criticism in interpretation (kritik sosial dalam penafsiran al-Qur'an). Sardar tidak hanya melakukan penafsiran al-Qur'an dalam arti "menjelaskan makna" saja (seperti

${ }^{59}$ MK Ridwan, "Metodologi Penafsiran Kontekstual: Analisis Gagasan dan Prinsip Kunci Penafsiran Kontekstual Abdullah Saeed", Jurnal Millati, 1, no. 1 (Juni 2016): 4, doi:http://dx.doi.org/10.18326/mlt.v1i1.1-22. 
mufassir pada umumnya), tetapi juga mampu menguak 'bentuk' lain al-Qur'an sebagai kritik sosial atas fenomena keberagamaan di masa kini.

\section{Bibliografi}

Anggoro, Taufan. (2019). Perkembangan Pemahaman Hadis di Indonesia: Analisis Pergeseran dan Tawaran di Masa Kini. Jurnal Diya' al-Afkar 7 (1), 2019. 147-166. Doi:http://10.24235/diyaafkar.v7i01.4533.

Fadilah, Adi \& Kusmana. (2018). Ziauddin Sardar's Interpretation of the Qur'an. Jurnal Education and Humanities Research (ASSEHR), 137, 319-323. Doi:http://10.2991/icqhs-17.2018.48.

al-Farmawi, Abdul Hayy. Metode Tafsir Maudu'i dan Cara Penerapannya terj. Rosihon Anwar. Bandung: Pustaka Setia, 2002.

Fina, Lien Iffah Nafatu. (2011). Interpretasi Kontekstual: Studi Pemikiran Hermeneutika al-Qur'an Abdulah Saeed. Jurnal Esensia, XII (1), 159-179. Doi:http://10.14421/esensia.v12i1.707.

Halim, Muhammad Abdul. Menafsirkan al-Qur'an dengan al-Qur'an. Bandung: MARJA, 2012.

Hasbiyallah, Muhammad. (2018). Paradigma Tafsir Kontekstual: Upaya Membumikan Nilai-Nilai al-Qur'an. Jurnal adz-Dzikera, XXII (1), 21-50. Doi:http:/ 10.24042/al-dzikra.v12i1.2924.

Ridwan, MK. (2016). Metodologi Penafsiran Kontekstual: Analisis Gagasan dan Prinsip Kunci Penafsiran Kontekstual Abdullah Saeed. Jurnal Millati, I (1), 1-22. Doi:http://dx.doi.org/10.18326/mlt.v1i1.1-22.

Sardar, Ziauddin. Merombak Pola Pikir Intelektual Muslim terj. Agung Prihantoro \& Fuad Arif Fudyartanto. Yogyakarta: Pustaka Pelajar, 2000.

. Islam Tanpa Syariat: Menggali Universalitas Tradisi, ed. Abdul Mu’ti \& Ahmad Najib Burhani. Jakarta: Grafindo Khazanah Ilmu, 2005.

. Reading The Qur'an: The Contemporary Relevance of The Sacred Text of Islam. New York: Oxford University Press, 2011.

Sa'dan, Masthuriyah. (2015). Islamic Science, Nature, and Human Beings: A Discussion on Ziauddin Sardar's Thoughts. Jurnal Walisongo, XXIII (2), 233-250. Doi:http://10.21580/ws.2015.23.2.278.

Solahudin, M. (2016). Pendekatan Tekstual dan Kontekstual dalam Penafsiran al-Qur'an. Jurnal al-Bayan, I (2), 115-130. Doi:http://10.15575/albayan.v1i2.1596. 
220 | AL QUDS : Jurnal Studi Alquran dan Hadis vol. 3, no 2, 2019

Sudarman. (2015). Pemikiran Farid Esack tentang Hermeneutika al-Qur'an. Jurnal al-Adyan, $\mathrm{X}$ (1), 83-98. Doi: https://doi.org/10.24042/ajsla.v10i1.1424.

Supena, Ilyas. Hermeneutika al-Qur'an dalam Pandangan Fazlur Rahman. Yogyakarta: Ombak, 2014.

Syamsuddin, Sahiron. Hermeneutika dan Pengembangan Ulumul Qur'an. Yogyakarta: Nawesea Press, 2009.

Wiwaha, Kurnia Sari. (2018). Epistemologi Paradigma Islam: Studi Pemikiran Ziauddin Sardar. Religious: Jurnal Studi Agama-Agama dan Lintas Budaya I (1), 2018. 70-79. Doi:https://10.15575/rjsalb.v3i1.3314.

http: https://ziauddinsardar.com/bibliography yang diakses pada tanggal 7 Juli 2019 Pukul 13.30 WIB 